Feature Article

\title{
Characteristics of Lowland Tropical Peatlands: Formation, Classification, and Decomposition
}

\author{
A.S. Ratnayake* \\ Department of Applied Earth Sciences, Faculty of Applied Sciences, Uva Wellassa University, \\ Badulla, Sri Lanka
}

\begin{abstract}
Tropical peatlands occur mostly in coastal lowlands, and it can be considered as larger sinkers of carbon and important ecosystem services for water resources, bio-resources and biodiversity. This article summarised characteristics, formation and classification of tropical lowland peatlands. Tropical peatlands cover about $11 \%$ of the global peatland resource $\left(441,025 \mathrm{~km}^{2}\right.$ in area) and the estimation value can be changed with including all histosols and shallow organic soils. Tropical coastal peatlands were predominantly developed during the middle to late Holocene (between 3,500 to 6,000 years BP) under the wet conditions generated after the stabilisation and regression of middle Holocene sea-level highstands. Hydrology is a fundamental factor to the formation and function of tropical peatlands. There is no specific definition for the peatlands based on available references. The available definitions can be broadly divided into authoritative and scientific definitions. The authoritative definitions depend on specific uses and applications, while scientific definitions depend on field observations and experimental design/analytical methods. Tropical peatlands store abundant organic matter. However, the recent anthropogenic activities enhance the emission of stored carbon as greenhouse gasses such as $\mathrm{CH}_{4}$ and $\mathrm{CO}_{2}$.
\end{abstract}

Keywords: mire, carbon accumulation, groundwater level, peatland disturbance, greenhouse gas emissions

\section{Introduction}

Peatlands are a unique terrestrial ecosystem that can act as an efficient terrestrial carbon sinker. For example, it is estimated that the total peat carbon burial is around $600 \mathrm{Gt} \mathrm{C} \mathrm{(Yu,} \mathrm{2011;} \mathrm{Charman} \mathrm{et}$ al., 2013). Peatlands consist of partially decomposed former terrestrial vegetation in various stages of humification under usually waterlogged and acidic conditions. Peatlands contain about $30 \%$ of the global soil carbon and $10 \%$ of the global freshwater aquifers (Tarnocai and Stolbovoy, 2006). These wetland ecosystems are characterised by a net accumulation of organic matter, as the rate of biomass production exceeds the rate of decomposition (Chimner and Ewel, 2005; Moore et al., 2013; Draper et al., 2014). Peatlands spread about $3 \%$ (i.e., about 5 million $\mathrm{km}^{2}$ ) of the global land area (Figure 1a). The prominent northern hemisphere peatlands (about $89 \%$ of total peatlands area) cover Russia, North America, and Europe (Immirzi et al., 1992; Rydin and Jeglum, 2013; Xu et al., 2018). The second larger tropical peatlands cover Southeast Asia, South America, and Africa. Tropical peatlands (about $11 \%$ of total peatlands area) contain around 50 to $70 \mathrm{Gt} \mathrm{C}$. In addition, tropical peatlands contribute $16-21 \%$ of global peat soil carbon pool (Gorham, 1991; Immirzi et al., 1992; Page et al., 2002).

*Correspondence: as_ratnayake@uwu.ac.lk

Tel: +94719445860

(C) University of Sri Jayewardenepura 


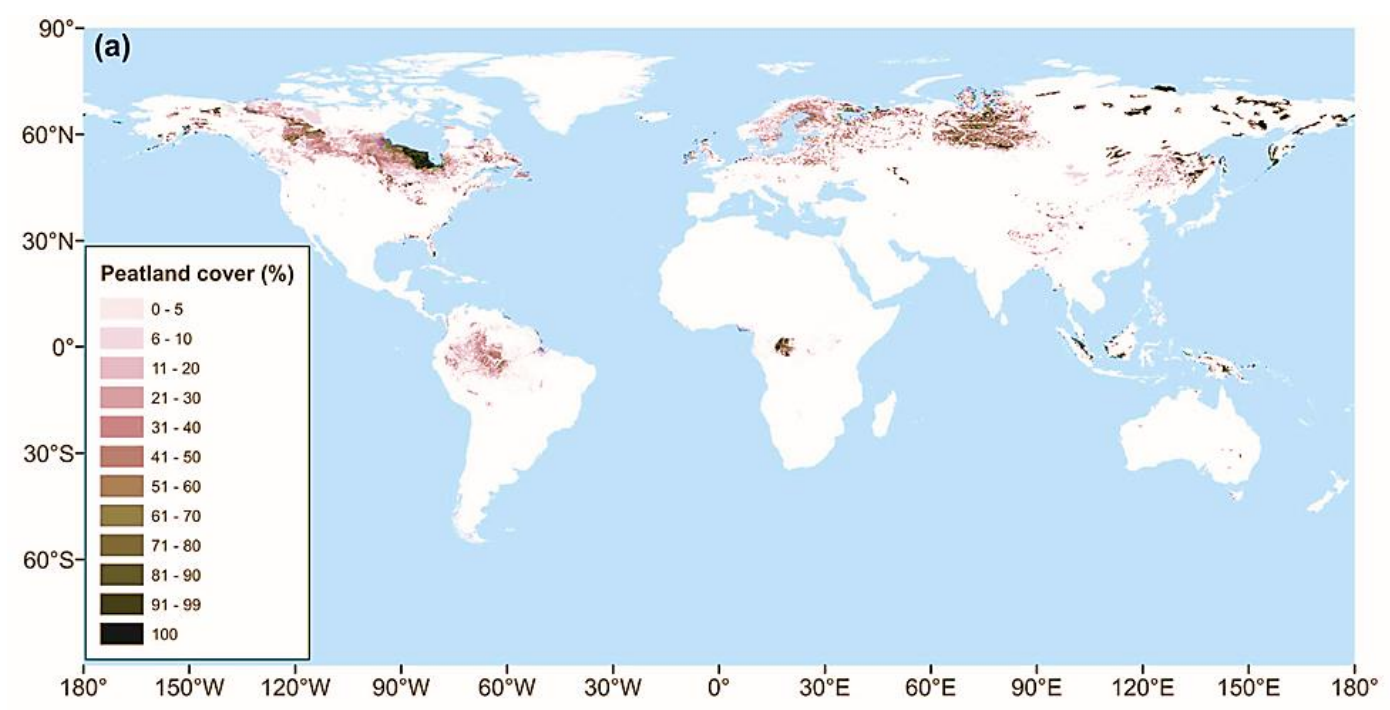

(b)

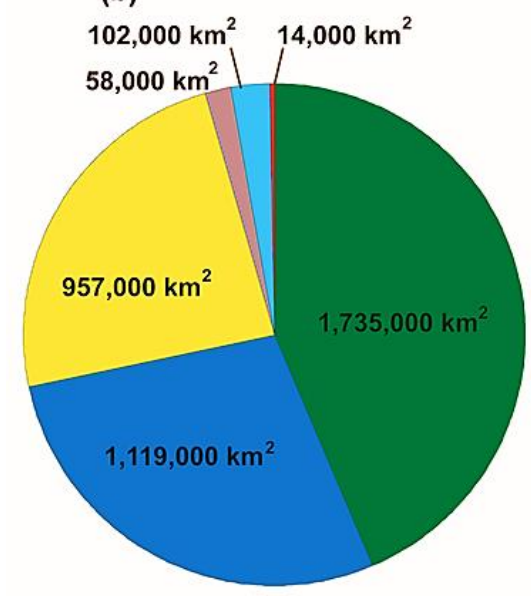

(i)

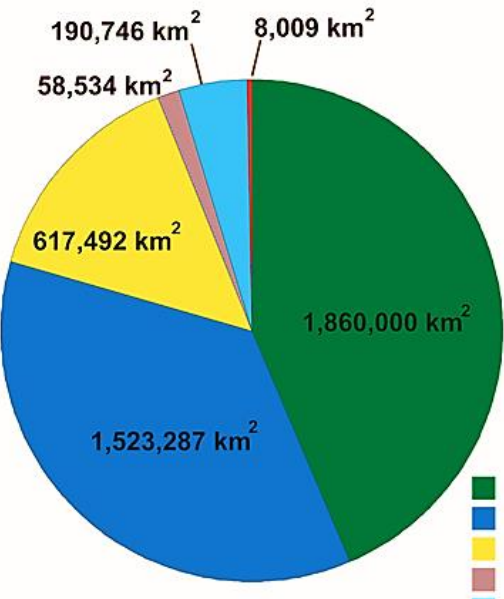

(ii)
North America Asia

Africa

Central and South America Australia and Oceania

Figure 1. (a) Global peatland distribution where peatland area was estimated based on histosols (source: $\mathrm{Xu}$ et al., 2008) and (b) pie charts showing peatland areas in different geographical regions of the world $\left(\mathrm{km}^{2}\right)$ based on raw data of (i) Lappalainen (1996) (best estimation, consider the provenance of data and assess the parameters) and (ii) Joosten and Clarke (2002) (maximum

estimation considering histosols and shallow organic soils).

Tropical peatlands can be further categorised as low altitude coastal peatlands (less than normally $30 \mathrm{~m}$ from mean sea-level) and mountain peatlands (altitude at least higher than 2,300 m) (Bosman et al., 1994; Page et al., 2006; Chimner and Karberg, 2008; Hribljan et al., 2016). The lowland tropical peatlands support a growing of swamp forests such as mangroves. However, mountain peatlands are considerably smaller than lowland coastal peatlands, and occurring mainly in basins and slopes of mountains. Tropical coastal peatlands are gradually exploited for several of human uses. Therefore, the rates of disturbance and destruction are currently high. Understanding of carbon cycle in tropical peatlands would help decision-makers for arranging protection and sustainable management activities. Consequently, this feature article outlines the distribution of tropical peatlands, genesis/formation processes, definition and classification, and recent anthropogenic disturbance of tropical peatlands based on published papers and documents. 


\section{Tropical Peatlands}

In tropic, peat is mainly formed under high precipitation and high-temperature conditions, and it is characterised by remains of branches, leaves, roots, and trunks of rainforest trees (Table 1). The largest area of tropical peatlands covers coastal lowlands, while tropical peatlands also found at higher altitudes. Several evaluations have been made to estimate the global and tropical areas and carbon accumulations of peatlands i.e., Armentano and Menges (1986), Gorham (1991), Immirzi et al. (1992), Joosten and Clarke (2002), Jaenicke et al. (2008), Donato et al. (2011), Page et al. (2011), Yu (2011), Kurnianto et al. (2015), Gallego-Sala et al. (2018), Xu et al. (2018). However, all these estimations have limitations and uncertainties due to (i) a lack of detailed information in a different geographical region (e.g. Central and South America, Africa, and South Asia), (ii) different definitions of peat, (iii) different survey methods, and (iv) the difficulty to carry out ground surveys in remote areas. For example, Lappalainen (1996) estimated that the peatland areas in North America, Asia, and Europe are 1,735,000 $\mathrm{km}^{2}, 1,119,000 \mathrm{~km}^{2}$, and 957,000 km², respectively (Figure 1b). However, Joosten and Clarke (2002) estimated that the peatland areas in North America, Asia, and Europe are 1,860,000 km², 1,523,287 $\mathrm{km}^{2}$, and $617,492 \mathrm{~km}^{2}$, respectively (Figure $1 \mathrm{~b}$ ).

Table 1: Characteristics of common peat materials.

\begin{tabular}{ll}
\hline Peat type & Dominant plant material \\
\hline Sphagnum & Sphagnum mosses (Sphagnum spp.) \\
Sedge & Sedges (Carex spp.) \\
Brown moss sedge & Brown mosses (Drepanocladus spp., Calliergon spp., Aulacomium spp.) and sedges \\
Woody sedge & Sedges and wood (derived from coniferous and deciduous tree species) \\
Woody & Wood \\
Feather moss & Feather mosses (Hypnum spp., Hylocomium spp., and Pleurozium spp. \\
Sedimentary & Aquatic plants (Algae, diatoms, aquatic mosses, and other aquatic organisms) \\
Amorphous & Not recognisable (Plant materials that are unspecified by the naked eye) \\
\hline
\end{tabular}

Page et al. (2011) carried out the best estimation on tropical peatlands between $23.5^{\circ} \mathrm{N}$ and $23.5^{\circ}$ $S$ considering the area, thickness and volume and carbon content of peat (Figure 2). The world's largest peatland locates in Southeast Asia, and the second and third larger peatlands locate in South America and Africa, respectively (Figure 2). According to Page et al. (2011), peat is defined as "the surface layer of soil, consisting mostly of partially decomposed vegetation, with at least $65 \%$ organic matter content in a minimum thickness of $30 \mathrm{~cm}$ ”. Besides, this estimation was done to assess the input of tropical peatlands to nation (by country), geographical/regional and global levels (Figure 2).

Tropical peatlands provide valuable ecological functions and environmental services such as biodiversity, water cycling, and commodities for exploitation (Maltby and Immirzi, 1993; Chimner and Ewel, 2005; Page et al., 2009; Donato et al., 2011; Alongi, 2012; Dubois et al., 2018). Tropical coastal peatlands support plant and animal species, develop buffer zone between saltwater and freshwater hydrological systems in coastal areas, and provide the socio-economic benefits (e.g. agriculture, food, shelter, medicine, etc.) for local communities. Besides, the vegetation of tropical coastal peatlands is characterised by unique adaptations such as viviparous embryos, aerial roots to tolerate salt, anoxic and waterlogged soils (Jaenicke et al., 2008; Alongi, 2012; Kurnianto et al., 2015). Therefore, these plants are limited at geographical scale. For example, the review of Posa et al. (2011) reported that 172 plant species (about 11\%) are only restricted to peat swamp forests out of recorded 1,524 plant species in peat swamp forests of Southeast Asia. 


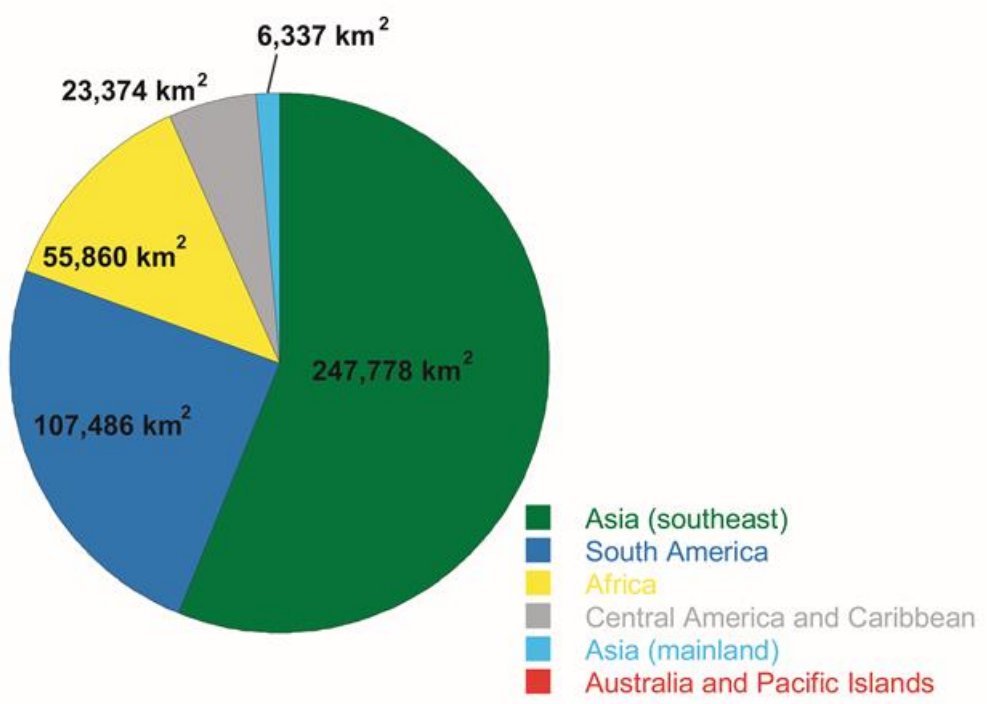

Figure 2. Pie chart showing tropical peatland areas in different geographical regions of the world $\left(\mathrm{km}^{2}\right)$ based on raw data of Page et al. (2011).

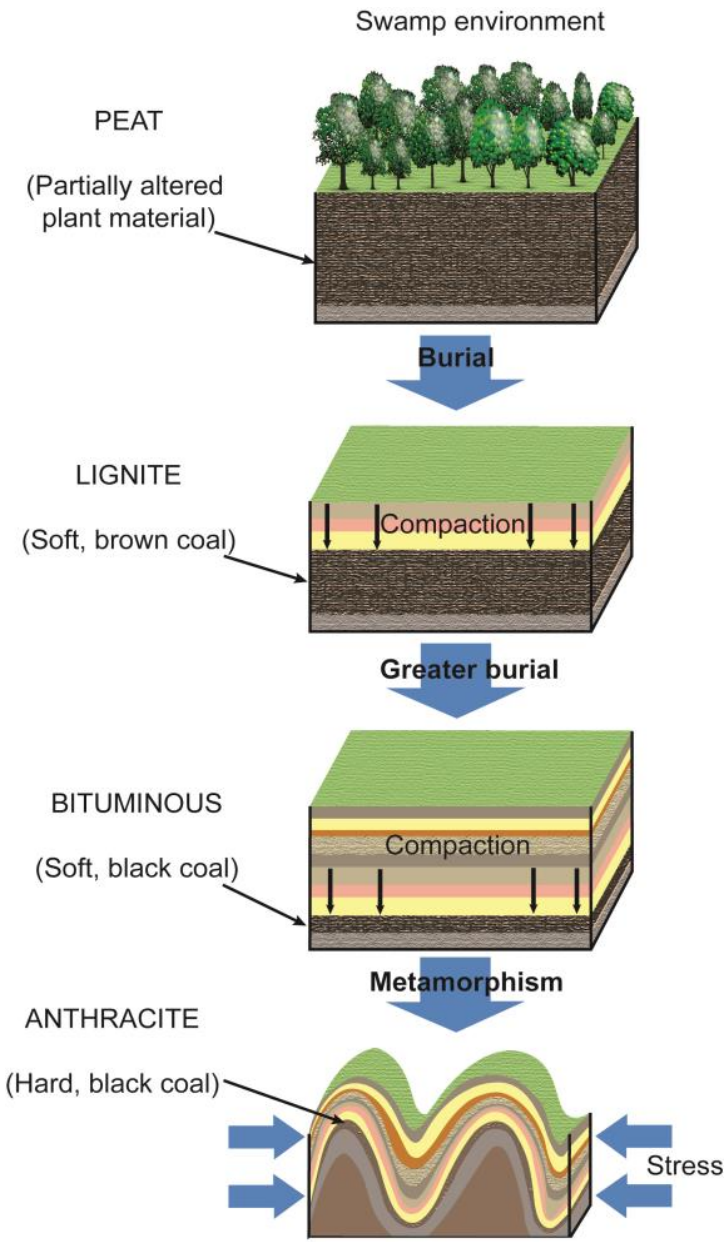


Figure 3. General trend of different types of coal production from peat swamp (mire).

Tropical peatlands contain about 2-3\% of the total soil carbon pool in the world (Gorham, 1991; Immirzi et al., 1992; Page et al., 2002, 2007). Consequently, tropical peatlands are important research areas for biogeochemistry and paleoenvironmental information. For example, paleo tropical peat deposits during the Carboniferous, Jurassic, Cretaceous and Miocene periods can be identified as the precursors of coal deposits (Esterle and Ferm, 1994; Phillips and Bustin, 1996, 1998; Wüst et al., 2003; Ratnayake and Sampei, 2015). Peat accumulation had expanded several tens of thousands of years under warm and humid climatic conditions and with a constant subsidence rate (Figure 3). It is estimated that about $3 \mathrm{~m}$ thick coal seams could be equivalent to about $25 \mathrm{~m}$ thick peat layer (Large et al., 2004). However, the modern tropical peatlands have rarely 6-8 m thick layer since most of the present tropical peat deposits formed after the last glacial maximum.

\section{Tropical Peat Formation}

Peat has mainly composed the remains of plant materials that deposit by the vegetation growing under different morphological conditions (Table 2). The near-surface peat layer is known as the acrotelm layer (oxic peat layer). This rooting zone is characterised by adding and decomposition of organic matter. However, plant nutrient elements are low in the acrotelm layer that can be influenced by plants growing. The underline anoxic layer (catotelm) is normally submerged below the water table and organic matter decomposition is low.

Table 2: Characteristics of peat classes.

\begin{tabular}{ll}
\hline $\begin{array}{l}\text { Peatland } \\
\text { class }\end{array}$ & Description \\
\hline Bogs & $\begin{array}{l}\text { Having water table at or near the surface. The bog surface raise or level with the surrounding } \\
\text { terrain. The dominant peat materials are weakly to moderately decomposed and acidic. E.g. } \\
\text { moss and woody peat. }\end{array}$ \\
Fens & $\begin{array}{l}\text { Having water table at or just below the surface. The dominant peat materials are moderately } \\
\text { to well decomposed and slightly acidic to neutral. E.g. sedge and/or brown moss peat. }\end{array}$ \\
Swamps & $\begin{array}{l}\text { Having water gently flowing through pools/channels. The dominant peat materials are well- } \\
\text { decomposed and strongly to slightly acidic. E.g. woody peat. } \\
\text { Periodically inundated by slowly- moving, nutrient-rich water. Surface water levels fluctuate } \\
\text { Marshes } \\
\text { seasonally. The dominant peat materials are well-decomposed and slightly acidic to neutral. } \\
\text { E.g. reeds and aquatic vegetation. }\end{array}$ \\
\hline
\end{tabular}

Organic matter decomposition is high (about 80\%) in the uppermost acrotelm layer. After that, about $10 \%$ of organic matter can be lost in the lowermost catotelm (Kuhry and Vitt, 1996; Turetsky et al., 2014). Carbon budget of peatlands is mainly controlled by microbial oxidation of organic fraction, and it is represented in equation 1.

$$
\mathrm{C}_{6} \mathrm{H}_{12} \mathrm{O}_{6}+6 \mathrm{O}_{2} \rightarrow 6 \mathrm{CO}_{2}+6 \mathrm{H}_{2} \mathrm{O}
$$

This reaction is mainly controlled by oxygen level, temperature and water saturation in soil. Therefore, organic matter preservation in peatlands can also relate to meteorological records. Geological conditions also play a key role in peat formation. Peatlands are generally formed on impermeable substrates such as clay that delay the drainage of surface water. The term mire is used to describe currently forming and accumulating active peatlands.

In tropics, peat forms normally under the hot and humid conditions that enhance production rates and decomposition rates, especially in leaves. Aboveground plant production can be identified as the 
primary source of peat (Table 1). Roots of plants also play an important role to accumulate peats in tropics due to its slower decomposition rates (Thormann et al., 2001; Chimner and Ewel, 2005). Tropical peat formation can be mainly explained using two major possible mechanisms considering microbial decomposition. Firstly, water-saturated humid conditions reduce microbial decomposition and preservation of terrestrial organic matter due to the reduction of oxygen deficiency (Chimner and Ewel, 2005; Page et al., 2006; Hirano et al., 2009). The constant water-saturated environment can be observed in the humid tropics since precipitation is higher than evaporation throughout the year. The high rainfall and waterlogged soils provide favorable conditions for peat accumulation and carbon storage. Therefore, peat decomposition and $\mathrm{CO}_{2}$ release would enhance due to a drop in groundwater table (i.e., increase oxic peat layer/the acrotelm) with decreasing either quantity or frequency of rainfall. The water budget of peatlands is represented in equation 2 .

$$
P+G \rightarrow \Delta(M, R)+Q+E
$$

where: $P=$ precipitation

$G=$ groundwater inflow

$M=$ soil water storage

$R=$ surface storage

$Q=$ runoff

$E=$ evapotranspiration

Secondly, unfavorable chemical conditions in soils such as high levels of sulfur especially in mangrove clay, acidity and high levels of fulvic acids and polyphenols in plant litters also reduce microbial decomposition and preservation of terrestrial organic matter (Bruenig, 1990; Hirano et al., 2009). Consequently, these two major processes promote the higher rate of terrestrial organic matter preservation than the decomposition.

Tropical peat deposits have been recorded in coastal plains and inland high altitude areas. Coastal peatlands are common in tropics that develop over marine sediments of clay and silt and 1-2 m above sea-level. This type of peatlands associated with mangrove swamps and brackish water bodies. The abundance of sulfides in brackish mangrove muds limits bacterial activities and it is the best explanation for the tropical mangrove peat formation. According to Page et al. (2004) and Rieley et al. (2008), tropical coastal peatlands have extensively developed during the middle Holocene. Besides, the formation of tropical coastal peatlands began under not only the wet climatic conditions and but also fluctuations in middle Holocene sea-level and coastal geomorphological changes. Paleoenvironmental studies suggested that lowland tropical coastal peatlands in Asia (mainland) commenced around 4,0005,000 cal yr BP followed by the stability of rising sea-levels (Anderson and Muller, 1975; Jaenicke et al., 2008; Dommain et al., 2011; Donato et al., 2011). Therefore, lowland tropical coastal peatlands is a primary feature of the Holocene. However, the initiation dates of most of the sub-coastal and inland peatlands commenced from the late Pleistocene (ca. 29,000 cal yr BP) to early Holocene $(9,000 \mathrm{cal} \mathrm{yr}$ BP) (Staub and Esterle, 1994; Page et al., 2004; Jaenicke et al., 2008; Dommain et al., 2011; Kurnianto et al., 2015).

The water availability/groundwater level plays a key role in formation and storage carbon and preserving biodiversity in peatlands (Hirano et al., 2009; Page et al., 2009; Yu et al., 2010; Charman et al., 2013; Turetsky et al., 2014). Deforestation, ecosystem change (farming) and drainage reduce the water content in peatlands (Figure 4). Fire, runoff of black carbon, microbial degradation also decreases a large amount of carbon contents in peatlands (Figure 4). Furthermore, microbial decomposition can enhance under the drop of groundwater level. The water table can be changed by decreasing tree growth 
and increasing tree mortality. Consequently, carbon balance in peatlands can be estimated by flux or loss of carbon followed by the groundwater level in peat.

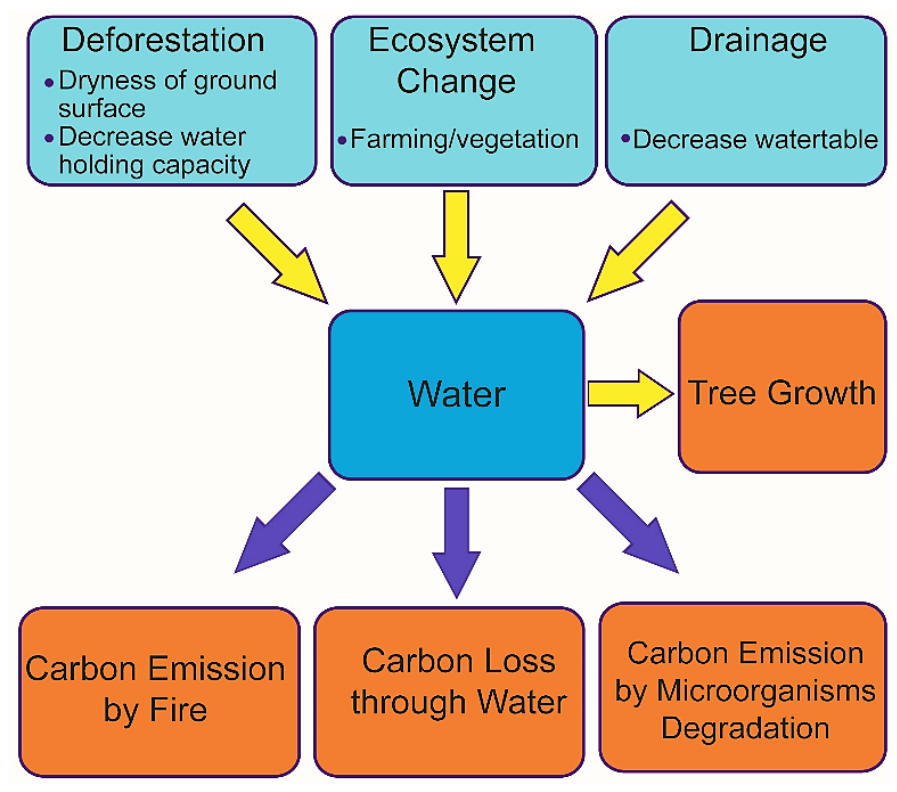

Figure 4. The effects of water to control carbon content as flux or loss from peatlands.

\section{Definition and Classification}

Several scientific definitions have been used to define peat and peatland based on countries and disciplines (Maltby and Immirzi, 1993; Yu et al., 2010; Page et al., 2011; Xu et al., 2018). Although the definition of peatland is most essential topics for policy design and implication, the Intergovernmental Panel on Climate Change (IPCC) also uses classification methods rather than a specific definition. According to the Ramsar Convention, "peatland are ecosystems with a peat deposit that may currently support vegetation that is peat-forming, may not, or may lack vegetation entirely. Peat is dead and partially decomposed plant remains that have accumulated in situ under waterlogged conditions". The available peatlands definitions can be broadly classified as authoritative and scientific. In general, the authoritative definitions depend on objectives (specific uses and applications), visions and missions of the organization. For example, three different authorities in Indonesia define peat in different ways.

According to the Ministry of Environment, "peat is a plant residue formed naturally through long-term decomposition processes, accumulating in swamp areas or static reservoirs". According to the Ministry of Agriculture, "peat is a soil formed as a result of organic matter accumulation with a naturally occurring composition of greater than $65 \%$ from the decaying vegetation growing on it, whose decomposition is slowed down by anaerobic and wet conditions". However, according to the Ministry of Forestry, "peat is an organic matter residue accumulating over a long period of time". Consequently, the differences in definition and data uncertainties can make significant gaps to reach national policy design and implication, and monitoring system.

Scientific definitions mainly depend on field observations and experimental designs such as types of data, methods, assumptions, analytical techniques and physical properties i.e., Kuhry and Vitt (1996), Wüst et al. (2003), Ballhorn et al. (2009), Yu et al. (2010), Page et al. (2011), Donato et al. (2011), Draper et al. (2014), Kurnianto et al. (2015), Gallego-Sala et al. (2018). For example, different physical properties (e.g. degree of decomposition/humification, bulk density, water content, porosity) 
and chemical properties (e.g. ash content, carbon content, $\mathrm{pH}$, and $\mathrm{C} / \mathrm{N}$ ratio) have been applied to define and classify peat/peatlands in the literature. Similarly, several peatland classifications have been used based on the shape/height of the peatlands, vegetation cover, water chemistry/hydrology, soils, etc.

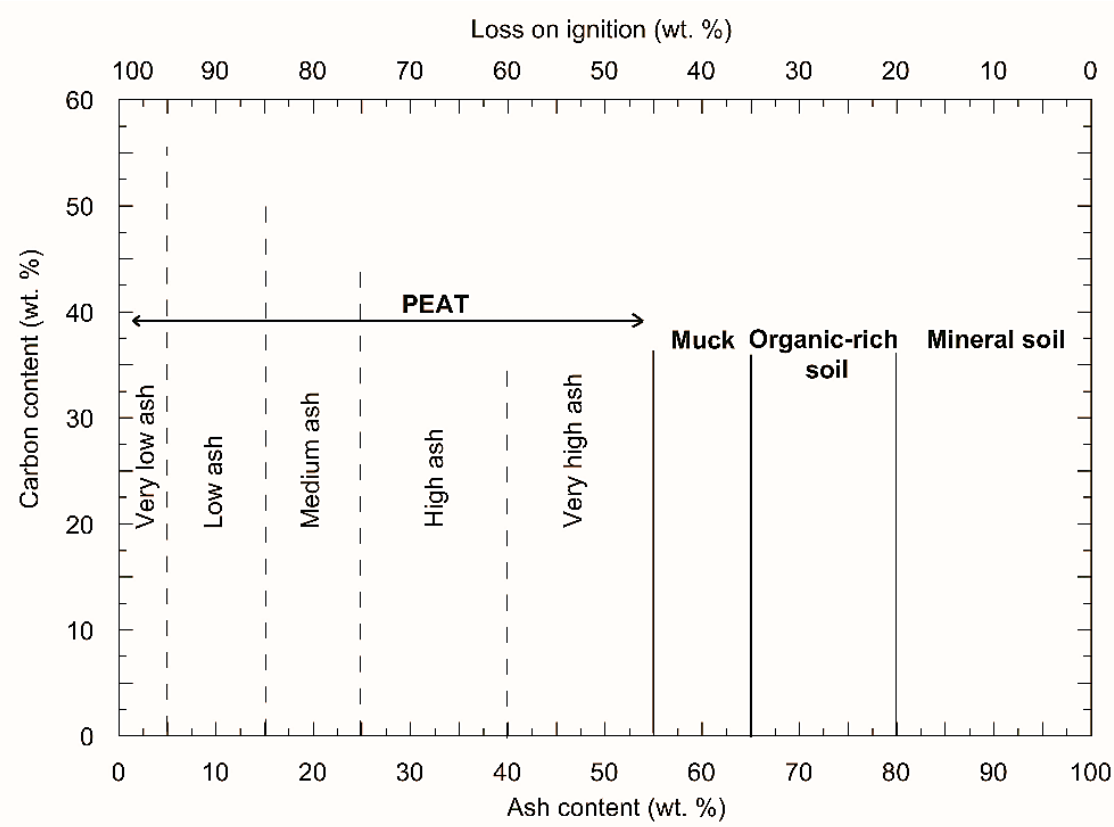

Figure 5. Classification diagram of tropical peatlands based on ash and carbon contents (modified after Wüst et al., 2003).

Wüst et al. (2003) proposed one of the best classifications for lowland tropical peatlands and organic soils based on ash and carbon contents (Figure 5). Tropical peatlands can be classified into several groups such as very low ash (0-5\%), low ash (5-15\%), medium ash (15-25\%), high ash (25$40 \%$ ), and very high ash (40-55\%) peats (Figure 5). Besides, ash content ( $\geq 35 \%)$, peat depth $(\geq 50 \mathrm{~cm})$ and carbon content $(\geq 12 \%)$ can be identified as key elements to define peatlands. The total organic carbon content of tropical peat is normally higher than $50 \%$ (wt.) and total nitrogen content is about $2 \%$ (wt.) (Kurnain et al., 2001; Wüst et al., 2003). However, C/N ratio can be varied in peatlands, and it increases normally with increasing depth due to preferential decomposition of organic matter (Kuhry and Vitt, 1996; Ratnayake et al., 2017). In contrast, it is difficult to distinguish muck and organic-rich mud in the field, as it is quite a gradual transition from peat to mineral soil.

Several physical and chemical properties such as wood content, microbial activity, degree of decomposition, stratification, compaction, and land-use practices have been controlled the nature of peatlands (Kurnain et al., 2001; Wüst et al., 2003; Yu et al., 2010; Turetsky et al., 2014; Dargie et al., 2017). Several analytical techniques also use to investigate the geochemistry of peatlands for different objectives. For example, biomarkers are molecules compounds derived from biological sources that can retain certain information such as origin, past depositional environment and climate in geological formations. Biomarker studies of non-emergent vascular plants consist of $\mathrm{C}_{21}, \mathrm{C}_{23}$ and $\mathrm{C}_{25} n$-alkanes, whereas vascular terrestrial plants consist of $\mathrm{C}_{27}, \mathrm{C}_{29}$ and $\mathrm{C}_{31} n$-alkanes (Meyers and Ishiwatari, 1993; Beilman et al., 2020; Freimuth et al., 2020). Ratnayake et al. (2019) examined the biomarker distribution of $n$-alkanes in several terrestrial ecosystems (Figure 6). A ternary $n-C_{27}-n-C_{29}-n-C_{31}$ diagram shows that peatlands are enriched in $n-\mathrm{C}_{31}$ due to the occurrence of grasses, floating plants herbaceous vegetation in swamps. Therefore, biomarkers provide unique information to distinguish peatlands, paleo-ecological 
changes and paleo-environments. Specific biomarkers such as terpenoids and multivariate analysis of a large set of organic compounds can also be applied for detailed information on vegetation changes, decomposition trends and climatic changes.

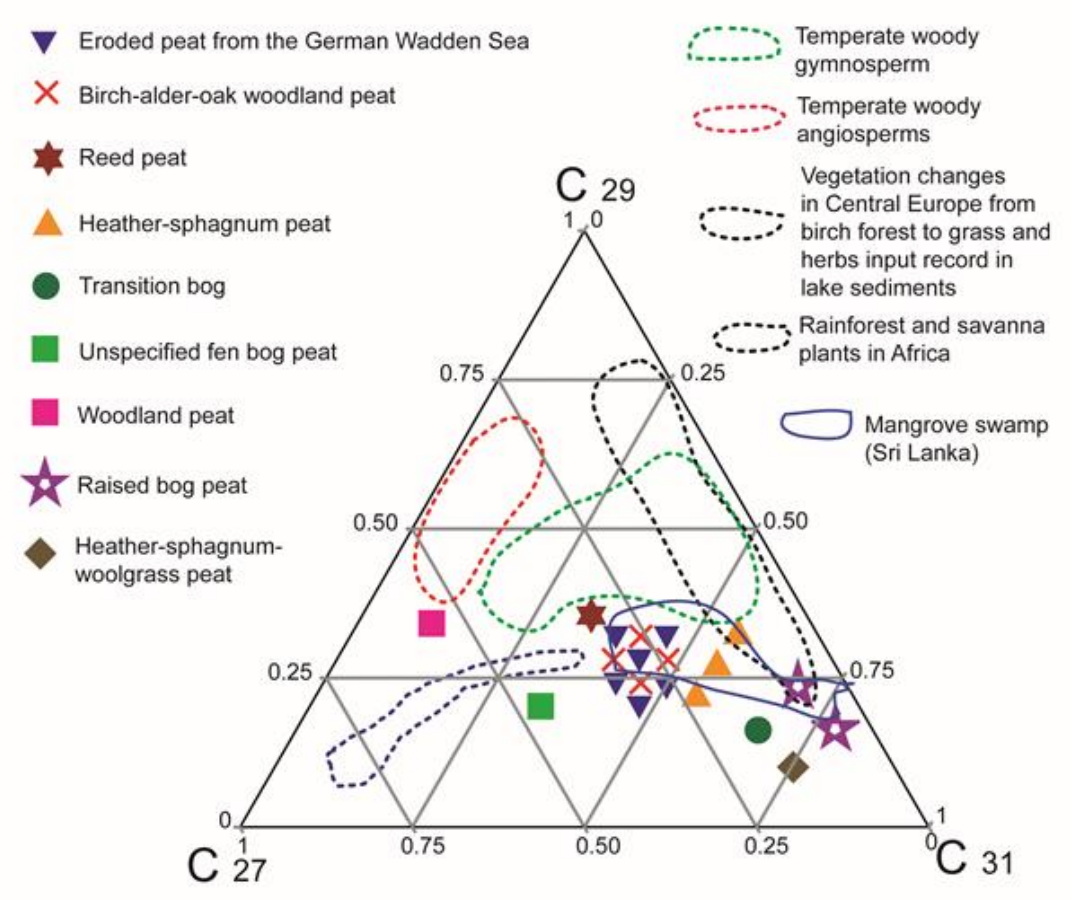

Figure 6. Ternary $n-\mathrm{C}_{27}, n-\mathrm{C}_{29}$ and $n-\mathrm{C}_{31} n$-alkanes diagram shows a comparison of mid-latitude and high-latitude peat bogs (i.e., eroded peat from the German Wadden Sea, birch-alder-oak woodland peat, reed peat, heather-sphagnum peat, transition bog, unspecified fen bog peat, woodland peat, raised bog peat, heather-sphagnum-woolgrass peat), vegetation changes from birch forest to grass and herbs in Central Europe, temperate woody gymnosperm and angiosperm and tropical brackish

lake sediments data from the literature (Volkman et al., 2000; Schwark et al., 2002; Bush and McInerney, 2013; Ratnayake et al., 2019).

\section{Greenhouse Gasses Emission from Peatlands}

Tropical peatlands can be identified as a hot spot for carbon and nitrogen burial (Canadell et al., 2007; Ratnayake et al., 2018; Beilman et al., 2020). In recent decades, tropical peatlands are under stress due to human-induced destructions. For example, land-use change/land degradation leads to release of stored carbon in the form of greenhouse gases that contribute to climate change (Ballhorn et al., 2009; Dommain et al., 2011; Alongi, 2012; Turetsky et al., 2014; Hribljan et al., 2016). Besides, carbon emissions from land-use change are the most uncertain component of the global carbon cycle. For example, Harris et al. (2012) estimated carbon emissions ( $\mathrm{Tg} \mathrm{C} \mathrm{year}^{-1}$ ) in the tropical region due to loss of gross forest cover between 2000 and 2005. According to Figure 7, Latin America and Caribean produced the highest carbon emission (384 $\mathrm{Tg} \mathrm{C}$ year $^{-1}$ ) between 2000 and 2005 and accounted for nearly $59 \%$ of total emissions from tropical deforestation. South and Southeast Asia produced $209 \mathrm{Tg}$ C year $^{-1}$ between 2000 and 2005 and accounted for nearly 32\% of total emissions from tropical deforestation (Figure 7). Furthermore, gross forest cover loss (Mha year ${ }^{-1}$ ) shows a positive correlation with carbon emissions ( $\mathrm{Tg} \mathrm{C}_{\mathrm{Cear}}{ }^{-1}$ ) in selected tropical forest areas (Figure 8). Similarly, anthropogenic activities and climatic changes (e.g. temperature) can become major drivers for the emission of $\mathrm{CO}_{2}$, 
$\mathrm{CH}_{4}$ and $\mathrm{N}_{2} \mathrm{O}$ from tropical peatlands (Jauhiainen et al., 2005; Hirano et al., 2009; Hooijer et al., 2010; Moore et al., 2013; Sjögersten et al., 2014).

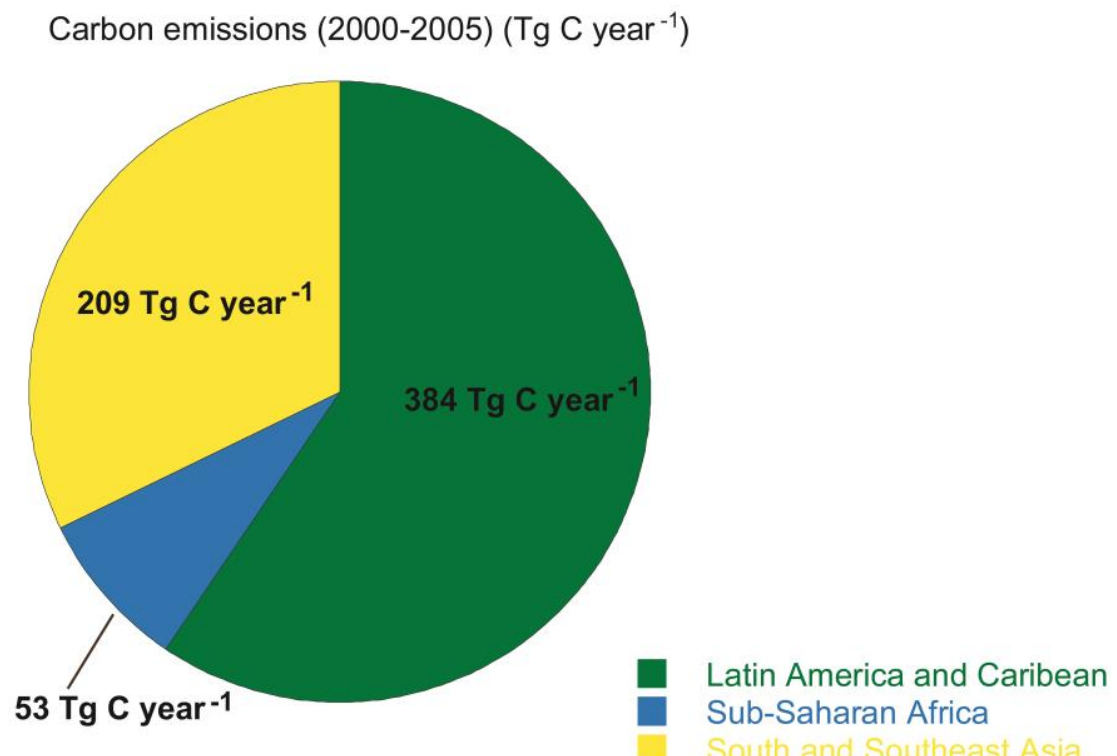

Figure 7. Carbon emissions ( $\mathrm{Tg} \mathrm{C}$ year ${ }^{-1}$ ) in different tropical geographical regions due to gross forest cover loss between 2000 and 2005. Raw data obtained from Harris et al. (2012).

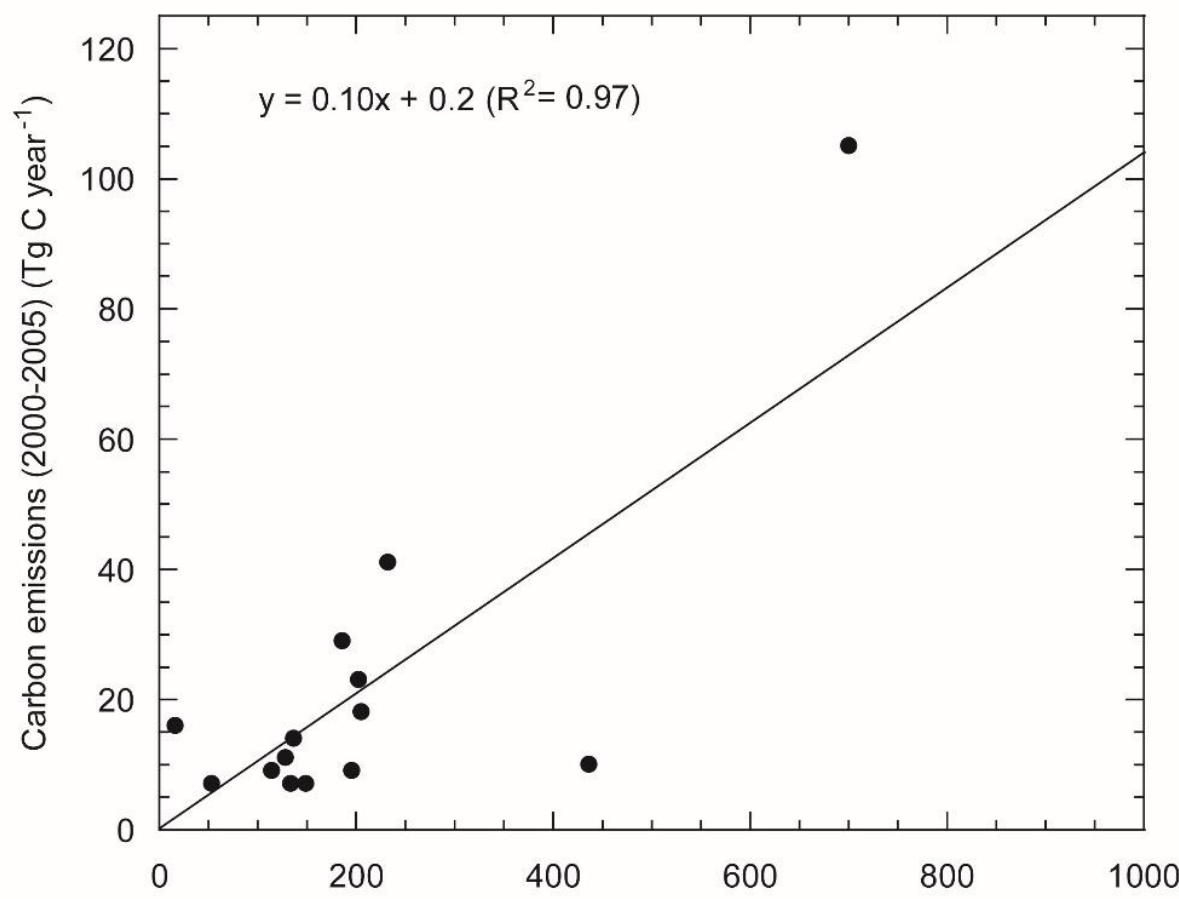

Gross forest cover loss (2000-2005) (Mha year ${ }^{-1}$ )

Figure 8. Relationship between carbon emissions ( $\mathrm{Tg} \mathrm{C}$ year ${ }^{-1}$ ) and gross forest cover loss $\left(\right.$ Mha year ${ }^{-1}$ ) in selected tropical forests. (Data points indicate Colombia, Bolivia, Argentina, 
Venezuela, the Democratic Republic of the Congo, Mozambique, Tanzania, Zambia, Cameroon, Indonesia, Malaysia, Myanmar, India and Thailand. Raw data were obtained from Hansen et al.

(2010) and Harris et al. (2012).

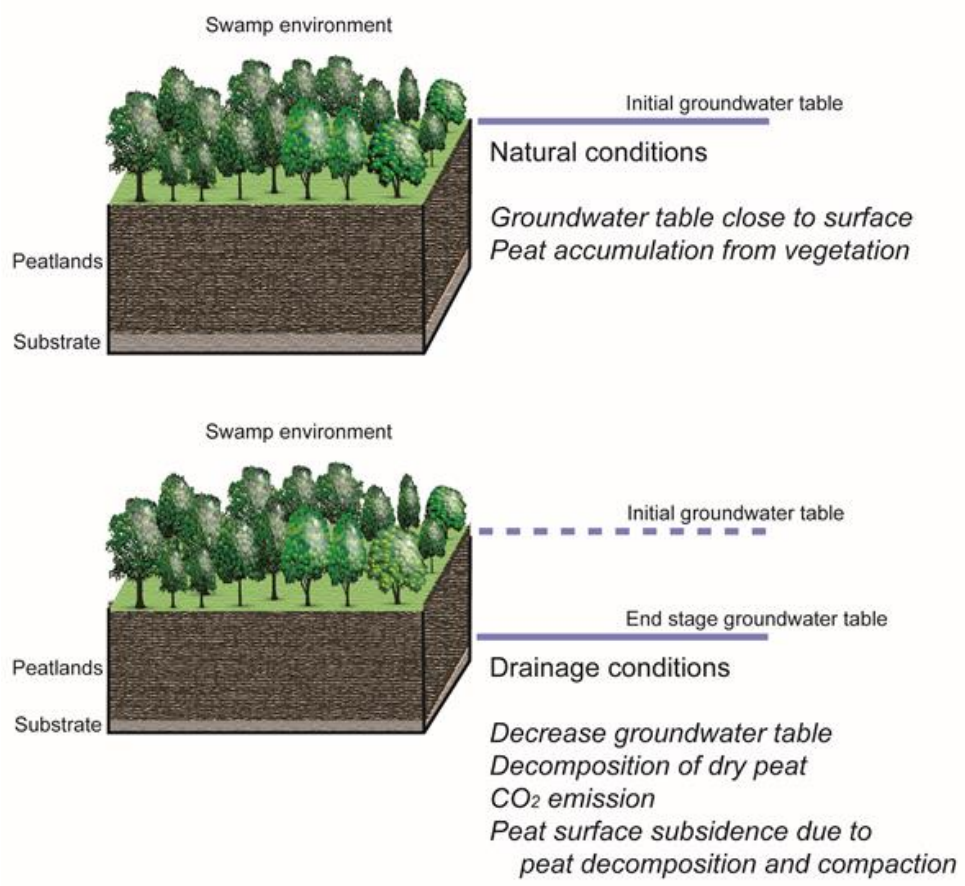

Figure 9. Schematic diagram shows " $\mathrm{CO}_{2}$ emissions from drainage-related peat decomposition".

In tropical peatlands, $\mathrm{CO}_{2}$ emission is more prominent than $\mathrm{CH}_{4}$ emission. However, it is estimated that undisturbed tropical wetlands also produce about 85 to $184 \mathrm{Tg}$ of $\mathrm{CH}_{4}$ each year (Sjögersten et al., 2014 and references therein). Besides, the emission of $\mathrm{CH}_{4}$ in tropical peatlands is normally low about $20 \%$ compared to temperate and boreal peatlands due to an abundance of hardly decomposable organic compounds such as lignin (Jauhiainen et al., 2005; Couwenberg et al., 2010). The net greenhouse gasses emission of peatlands is controlled by several components such as (i) net $\mathrm{CO}_{2}$ absorbed by vegetation, (ii) $\mathrm{CO}_{2}$ emission due to drainage-related peat decomposition and peat fires, (iii) exports of dissolved and particulate organic carbon, and (iv) minor emissions of $\mathrm{CH}_{4}$ and possibly $\mathrm{N}_{2} \mathrm{O}$. However, " $\mathrm{CO}_{2}$ emissions from drainage-related peat decomposition" can be identified as the dominant component for the greenhouse gasses emission from the peatlands. The drop of the groundwater table promotes aerobic microbial activity and enhances $\mathrm{CO}_{2}$ release by peat decomposition (Figure 9). Similarly, Moore et al. (2013) discussed nature of the fluvial carbon losses under the drainage and deforestation on tropical peatland.

\section{Sustainable Management of Peatlands in Sri Lanka}

Peatlands in Sri Lanka are located mostly along the south to west coasts as isolated patches. Muthurajawerla swamp is the largest coastal peat deposit in Sri Lanka that covers about $21 \mathrm{~km}^{2}$. The average thickness of this peat deposit is about $3.7 \mathrm{~m}$, and the maximum thickness is about $5.0 \mathrm{~m}$. The pH values of Muthurajawerla swamp range from 3 to 5 (Dissanayake et al., 1982). The color of peat varies from grey to black. The texture of peat varies from spongy to fibrous. Organic geochemical studies 
suggested that total organic carbon and total nitrogen contents increase up to $58.0 \%$ and $1.4 \%$, respectively (Dissanayake et al., 1982). The water level is about $15-30 \mathrm{~cm}$ high above the surface during wet season, and the water level drops to surface level during the dry season. Three types of peat can be recognised in Muthurajawerla swamps, namely (i) shrub and tree group (contain mainly the remains of trunks, roots and shrubs), (ii) reed and sedge group (contain mainly reeds, sedges, and other grasses vegetation in the swamp), (iii) human group (contain mainly decomposed peat and difficult to identify original vegetation).

High altitude peatlands are also located in Nuwara Eliya Mountains (e.g. Horton Plains) in Sri Lanka with an altitude greater than $2,200 \mathrm{~m}$. Previous investigations suggested that initial peat accumulation began ca. 17,100 cal year BP in the deeper part of valley bottoms in the Horton Plains. Peat formation enhanced after 7,800 cal year BP, corresponding to climatic changes (Premathilake and Risberg, 2003). Pollen analysis further suggested that Gaultheria leschenaultii, Psychotria zeylanica, Rubus leucocarpus, and Symplocos bractealis have been associated with peat accumulation in the Horton Plains (Premathilake et al., 1999). On the other hand, it is important to take necessary actions for peatland/wetland management in Sri Lanka to conserve and mitigate the existent of damages.

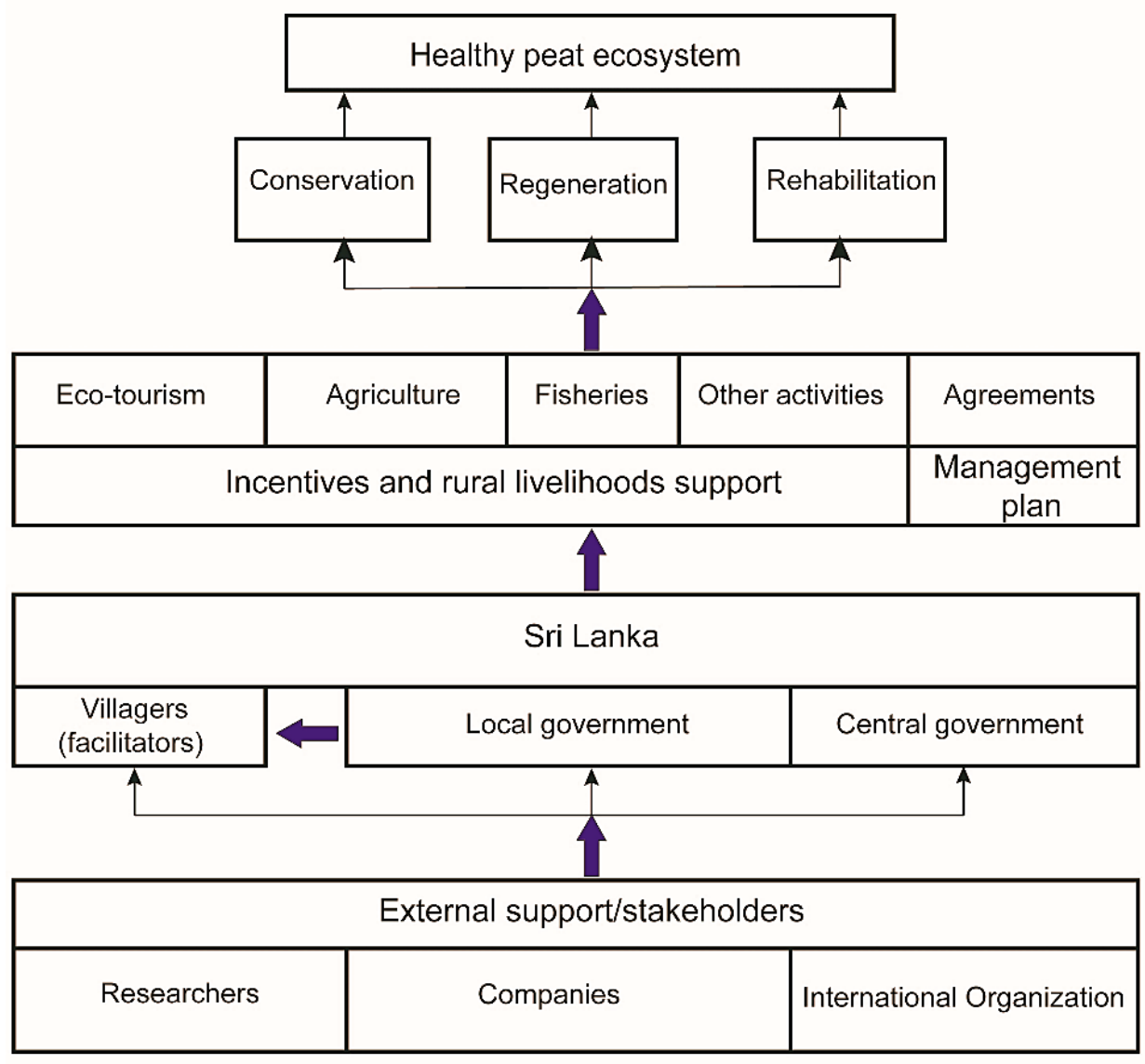

Figure 10. Sustainable management model for peatland in Sri Lanka.

Most of the governments in developed countries have been identified the utilisation of peatlands sustainably. However, practices of sustainable management are largely lacking due to inadequate assessment in most of the developing countries in the tropics. Consequently, it is important to manage tropical peatlands sustainably for conserving resources and generating maximum benefits for current and future generations. The proposed model (Figure 10) can be implemented for strategic sustainable 
management in tropical coastal peatlands in Sri Lanka. This strategy involves evaluation of function and uses (ecology, hydrology, biodiversity, and carbon storage), understanding of stakeholders and challenges facing during the management and implementation of socio-economic, cultural and ecological management plans for mitigation past, present and future damages.

\section{Acknowledgement}

This research was supported by the Accelerating Higher Education Expansion and Development (AHEAD) Operation of the Ministry of Higher Education funded by the World Bank. I would like to further acknowledge Jiren Xu, University of Leeds, UK for providing copyright permission of the PEATMAP. K.H.M. Sudesh is thanked for the assistance made to compile figures.

\section{References}

Alongi, D.M., 2012. Carbon sequestration in mangrove forests. Carbon Management, 3:313-322.

Anderson, J.A.R. and Muller, J., 1975. Palynological study of a Holocene peat and a Miocene coal deposit from NW Borneo. Review of Palaeobotany and Palynology, 19:291-351.

Armentano, T.V. and Menges, E.S., 1986. Patterns of change in the carbon balance of organic soilwetlands of the temperate zone. The Journal of Ecology, 74:755-774.

Ballhorn, U., Siegert, F., Mason, M. and Limin, S., 2009. Derivation of burn scar depths and estimation of carbon emissions with LIDAR in Indonesian peatlands. Proceedings of the National Academy of Sciences, 106:21213-21218.

Beilman, D.W., Massa, C., Nichols, J.E., Timm, O.E., Kallstrom, R. and Dunbar-Co, S., 2020. Dynamic Holocene vegetation and North Pacific hydroclimate recorded in a mountain peatland, Moloka' $\mathrm{i}$, Hawai'i. Frontiers in Earth Science, 7:188.

Bosman, A.F., Hooghiemstra, H. and Cleef, A.M., 1994. Holocene mire development and climatic change from a high Andean Plantago rigida cushion mire. The Holocene, 4:233-243.

Bruenig, E.F., 1990. Oligotrophic forested wetlands in Borneo. Ecosystems of the World, 15:299-334.

Bush, R.T. and McInerney, F.A., 2013. Leaf wax $n$-alkane distributions in and across modern plants: implications for paleoecology and chemotaxonomy. Geochimica et Cosmochimica Acta, 117:161-179.

Canadell, J.G., Pataki, D.E., Gifford, R., Houghton, R.A., Luo, Y., Raupach, M.R. and Steffen, W., 2007. Saturation of the terrestrial carbon sink. In: Terrestrial ecosystems in a changing world, Springer, Berlin, Heidelberg, pp. 59-78.

Charman, D.J., Beilman, D.W., Jackson, S.T., Korhola, A., Mauquoy, D., Mitchell, F.J. and Alm, J., 2013. Climate-related changes in peatland carbon accumulation during the last millennium. Biogeosciences, 10:929-944.

Chimner, R.A. and Ewel, K.C., 2005. A tropical freshwater wetland: II. Production, decomposition, and peat formation. Wetlands Ecology and Management, 13:671-684.

Chimner, R.A. and Karberg, J.M., 2008. Long-term carbon accumulation in two tropical mountain peatlands, Andes Mountains, Ecuador. Mires and Peat, 3:1-10.

Couwenberg, J., Dommain, R. and Joosten, H., 2010. Greenhouse gas fluxes from tropical peatlands in south-east Asia. Global Change Biology, 16:1715-1732.

Dargie, G.C., Lewis, S.L., Lawson, I.T., Mitchard, E.T., Page, S.E., Bocko, Y.E. and Ifo, S.A., 2017. Age, extent and carbon storage of the central Congo Basin peatland complex. Nature, 542:86-90.

Dissanayake, C.B., Senaratne, A. and Gunatilaka, A.L., 1982. Organic geochemical studies of the Muthurajawela peat deposit of Sri Lanka. Organic Geochemistry, 4:19-26. 
Dommain, R., Couwenberg, J. and Joosten, H., 2011. Development and carbon sequestration of tropical peat domes in south-east Asia: links to post-glacial sea-level changes and Holocene climate variability. Quaternary Science Reviews, 30:999-1010.

Donato, D.C., Kauffman, J.B., Murdiyarso, D., Kurnianto, S., Stidham, M. and Kanninen, M., 2011. Mangroves among the most carbon-rich forests in the tropics. Nature Geoscience, 4:293-297.

Draper, F.C., Roucoux, K.H., Lawson, I.T., Mitchard, E.T., Coronado, E.N.H., Lähteenoja, O. and Baker, T.R. 2014. The distribution and amount of carbon in the largest peatland complex in Amazonia. Environmental Research Letters, 9:124017.

Dubois, N., Saulnier-Talbot, É., Mills, K., Gell, P., Battarbee, R., Bennion, H. and Gomes, D.F., 2018. First human impacts and responses of aquatic systems: A review of palaeolimnological records from around the world. The Anthropocene Review, 5:28-68.

Esterle, J.S. and Ferm, J.C., 1994. Spatial variability in modern tropical peat deposits from Sarawak, Malaysia and Sumatra, Indonesia: analogues for coal. International Journal of Coal Geology, 26:1-41.

Freimuth, E.J., Diefendorf, A.F., Lowell, T.V., Bates, B.R., Schartman, A., Bird, B.W. and Stewart, A. K., 2020. Contrasting sensitivity of lake sediment $n$-alkanoic acids and $n$-alkanes to basin-scale vegetation and regional-scale precipitation $\delta^{2} \mathrm{H}$ in the Adirondack Mountains, NY (USA). Geochimica et Cosmochimica Acta, 268:22-41.

Gallego-Sala, A.V., Charman, D.J., Brewer, S., Page, S.E., Prentice, I.C., Friedlingstein, P. and Blyakharchuk, T., 2018. Latitudinal limits to the predicted increase of the peatland carbon sink with warming. Nature Climate Change, 8:907-913.

Gorham, E., 1991. Northern peatlands: role in the carbon cycle and probable responses to climatic warming. Ecological Applications, 1:182-195.

Hansen, M.C., Stehman, S.V., Potapov, P.V., Loveland, T.R., Townshend, J.R., DeFries, R.S. and Carroll, M., 2008. Humid tropical forest clearing from 2000 to 2005 quantified by using multitemporal and multiresolution remotely sensed data. Proceedings of the National Academy of Sciences, 105:9439-9444.

Harris, N.L., Brown, S., Hagen, S.C., Saatchi, S.S., Petrova, S., Salas, W. and Lotsch, A., 2012. Baseline map of carbon emissions from deforestation in tropical regions. Science, 336:1573-1576.

Hirano, T., Jauhiainen, J., Inoue, T. and Takahashi, H., 2009. Controls on the carbon balance of tropical peatlands. Ecosystems, 12:873-887.

Hooijer, A., Page, S., Canadell, J.G., Silvius, M., Kwadijk, J., Wösten, H. and Jauhiainen, J., 2009. Current and future $\mathrm{CO}_{2}$ emissions from drained peatlands in Southeast Asia. Biogeosciences, 7:1505-1514.

Hribljan, J.A., Suárez, E., Heckman, K.A., Lilleskov, E.A. and Chimner, R.A., 2016. Peatland carbon stocks and accumulation rates in the Ecuadorian páramo. Wetlands Ecology and Management, 24:113-127.

Immirzi, C.P., Maltby, E. and Clymo, R.S., 1992. The global status of peatlands and their role in carbon cyclking. London:Friends of the Earth, pp. 1-145

Jaenicke, J., Rieley, J.O., Mott, C., Kimman, P. and Siegert, F., 2008. Determination of the amount of carbon stored in Indonesian peatlands. Geoderma, 147:151-158.

Jauhiainen, J., Takahashi, H., Heikkinen, J.E., Martikainen, P. J. and Vasander, H., 2005. Carbon fluxes from a tropical peat swamp forest floor. Global Change Biology, 11:1788-1797.

Joosten, H. and Clarke, D., 2002. Wise use of mires and peatlands. International Mire Conservation Group and International Peat Society, 304.

Kuhry, P. and Vitt, D.H., 1996. Fossil carbon/nitrogen ratios as a measure of peat decomposition. Ecology, 77:271-275. 
Kurnain, A., Notohadikusumo, T., Radjagukguk, B. and Hastuti, S., 2001. Peat soil properties related to degree of decomposition under different land use systems. International Peat Journal, 11:67-77.

Kurnianto, S., Warren, M., Talbot, J., Kauffman, B., Murdiyarso, D. and Frolking, S., 2015. Carbon accumulation of tropical peatlands over millennia: a modeling approach. Global Change Biology, 21:431-444.

Lappalainen, E., 1996. Global peat resources. Finland: International Peat Society, Vol. 4, p. 358.

Large, D.J., Jones, T.F., Briggs, J., Macquaker, J.H. and Spiro, B.F., 2004. Orbital tuning and correlation of 1.7 my of continuous carbon storage in an early Miocene peatland. Geology, 32:873-876.

Maltby, E. and Immirzi, P., 1993. Carbon dynamics in peatlands and other wetland soils regional and global perspectives. Chemosphere, 27:999-1023.

Meyers, P.A. and Ishiwatari, R., 1993. Lacustrine organic geochemistry-an overview of indicators of organic matter sources and diagenesis in lake sediments. Organic Geochemistry, 20:867-900.

Moore, S., Evans, C.D., Page, S.E., Garnett, M.H., Jones, T.G., Freeman, C. and Gauci, V., 2013. Deep instability of deforested tropical peatlands revealed by fluvial organic carbon fluxes. Nature, 493:660-663.

Page, S., Hosciło, A., Wösten, H., Jauhiainen, J., Silvius, M., Rieley, J. and Limin, S., 2009. Restoration ecology of lowland tropical peatlands in Southeast Asia: current knowledge and future research directions. Ecosystems, 12:888-905.

Page, S.E., Banks, C.J. and Rieley, J.O., 2007. Tropical peatlands: distribution, extent and carbon storage-uncertainties and knowledge gaps. Peatlands International, 2:26-27.

Page, S.E., Rieley, J.O. and Banks, C.J., 2011. Global and regional importance of the tropical peatland carbon pool. Global Change Biology, 17:798-818.

Page, S.E., Rieley, J.O. and Wüst, R., 2006. Lowland tropical peatlands of Southeast Asia. Developments in Earth Surface Processes, 9:145-172.

Page, S.E., Siegert, F., Rieley, J.O., Boehm, H.D.V., Jaya, A. and Limin, S., 2002. The amount of carbon released from peat and forest fires in Indonesia during 1997. Nature, 420:61-65.

Page, S.E., Wüst, R.A.J., Weiss, D., Rieley, J.O., Shotyk, W. and Limin, S.H., 2004. A record of Late Pleistocene and Holocene carbon accumulation and climate change from an equatorial peat bog (Kalimantan, Indonesia): implications for past, present and future carbon dynamics. Journal of Quaternary Science, 19:625-635.

Phillips, S. and Bustin, R.M., 1996. Sulfur in the Changuinola peat deposit, Panama, as an indicator of d the environments of deposition of peat and coal. Journal of Sedimentary Research, 66:184-196.

Phillips, S. and Bustin, R.M., 1998. Accumulation of organic rich sediments in a dendritic fluvial/lacustrine mire system at Tasik Bera, Malaysia: implications for coal formation. International Journal of Coal Geology, 36:31-61.

Posa, M.R.C., Wijedasa, L.S. and Corlett, R.T., 2011. Biodiversity and conservation of tropical peat swamp forests. BioScience, 61:49-57.

Premathilake, R., Epitawatta, S. and Nilsson, S., 1999. Pollen morphology of some selected plant species from Horton Plains, Sri Lanka. Grana, 38:289-295.

Premathilake, R. and Risberg, J., 2003. Late Quaternary climate history of the Horton Plains, central Sri Lanka. Quaternary Science Reviews, 22:1525-1541.

Ratnayake, A.S., Ratnayake, N.P., Sampei, Y., Vijitha, A.V.P. and Jayamali, S.D., 2018. Seasonal and tidal influence for water quality changes in coastal Bolgoda Lake system, Sri Lanka. Journal of Coastal Conservation, 22:1191-1199.

Ratnayake, A.S. and Sampei, Y., 2015. Characterization of organic matter and depositional environment of the jurassic small sedimentary basins exposed in the northwest onshore area of Sri Lanka. Researches in Organic Geochemistry, 31:15-28. 
Ratnayake, A.S., Sampei, Y. and Ratnayake, N.P., 2019. Characteristics of sedimentary organic matter and vascular plants in tropical brackish Bolgoda Lake, Sri Lanka: Implications for paleoecology and chemotaxonomy. Regional Studies in Marine Science, 30:100726.

Ratnayake, A.S., Sampei, Y., Ratnayake, N.P. and Roser, B.P., 2017. Middle to late Holocene environmental changes in the depositional system of the tropical brackish Bolgoda Lake, coastal southwest Sri Lanka. Palaeogeography Palaeoclimatology Palaeoecology, 465:122-137.

Rieley, J.O., Wüst, R.A.J., Jauhiainen, J., Page, S.E., Wösten, J.H.M., Hooijer, A. and Stahlhut, M., 2008. Tropical peatlands: carbon stores, carbon gas emissions and contribution to climate change processes. In: Peatlands and climate change, International Peat Society, pp. 148-181.

Rydin, H. and Jeglum, J.K., 2013. The biology of peatlands. $2^{\text {nd }}$ Ed., Oxford University Press, UK.

Schwark, L., Zink, K. and Lechterbeck, J., 2002. Reconstruction of postglacial to early Holocene vegetation history in terrestrial Central Europe via cuticular lipid biomarkers and pollen records from lake sediments. Geology, 30:463-466.

Sjögersten, S., Black, C.R., Evers, S., Hoyos-Santillan, J., Wright, E.L. and Turner, B.L., 2014. Tropical wetlands: A missing link in the global carbon cycle?. Global Biogeochemical Cycles, 28:13711386.

Staub, J.R. and Esterle, J.S., 1994. Peat-accumulating depositional systems of Sarawak, East Malaysia. Sedimentary Geology, 89:91-106.

Tarnocai, C. and Stolbovoy, V., 2006. Northern peatlands: their characteristics, development and sensitivity to climate change. Developments in Earth Surface Processes, 9:17-51.

Thormann, M.N. and Bayley, S.E., 1997. Decomposition along a moderate-rich fen-marsh peatland gradient in boreal Alberta, Canada. Wetlands, 17:123-137.

Turetsky, M.R., Benscoter, B., Page, S., Rein, G., Van Der Werf, G.R. and Watts, A., 2015. Global vulnerability of peatlands to fire and carbon loss. Nature Geoscience, 8:11-14.

Volkman, J.K., Rohjans, D., Rullkötter, J., Scholz-Böttcher, B.M. and Liebezeit, G., 2000. Sources and diagenesis of organic matter in tidal flat sediments from the German Wadden Sea. Continental Shelf Research, 20:1139-1158.

Wüst, R.A., Bustin, R.M. and Lavkulich, L.M., 2003. New classification systems for tropical organicrich deposits based on studies of the Tasek Bera Basin, Malaysia. Catena, 53:133-163.

Xu, J., Morris, P.J., Liu, J. and Holden, J., 2018. PEATMAP: Refining estimates of global peatland distribution based on a meta-analysis. Catena, 160:134-140.

$\mathrm{Yu}, \mathrm{Z}$., 2011. Holocene carbon flux histories of the world's peatlands: Global carbon-cycle implications. The Holocene, 21:761-774.

Yu, Z., Loisel, J., Brosseau, D.P., Beilman, D.W. and Hunt, S.J., 2010. Global peatland dynamics since the Last Glacial Maximum. Geophysical Research Letters, 37. 